\title{
CLEAN SLATE 1 REVEGETATION AND MONITORING PLAN
}

\author{
AECENEN \\ DEC 23 1995 \\ Prepared for \\ OSTI \\ U.S. Department of Energy \\ Nevada Operations Office \\ Environmental Restoration Division \\ Las Vegas, Nevada
}

Prepared by

Bechtel Nevada

Ecological Services

P.O. Box 98521

Las Vegas, Nevada 89193-8521

DSTRPISUTION OF THIS DOCUMENT IS UNEIMITED

in

September 1996 


\section{DISCLAMMER}

Portions of this document may be illegible in electronic image products. Images are produced from the best available original document. 


\section{DISCLAIMER NOTICE}

This Report was prepared as an account of work sponsored by an agency of the U.S. Government. Neither the U.S. Government nor any agency thereof, nor any of their employees, makes any warranty or representation, express or implied, or assumes any legal liability or responsibility for the accuracy, completeness, or usefulness of any information, apparatus, product, or process disclosed, or represents that its use would not infringe privately owned rights. Reference herein to any specific commercial product, process, or service by trade name, trademark, manufacturer, or otherwise does not necessarily constitute or imply its endorsement, recommendation, or favoring by the United States Government or any agency thereof. The views and opinions of authors expressed herein do not necessarily state or reflect those of the United States Government or any agency thereof.

This report has been reproduced from the best available copy.

Available to DOE and DOE contractors from the Office of Scientific and Technical Information, P.O. Box 62, Oak Ridge, TN 37831. (615) 576-8401.

Available to the public from the National Technical Information Service, U.S. Department of Commerce, 5285 Port Royal Road, Springfield, VA 22161. (703) 487-4650. 


\section{TABLE OF CONTENTS}

\section{SECTION}

PAGE

1.0 INTRODUCTION $\ldots \ldots \ldots \ldots \ldots \ldots \ldots \ldots \ldots \ldots \ldots \ldots \ldots$

1.1 Physical Setting and Location of Cleanup Site $\ldots \ldots \ldots \ldots \ldots \ldots$

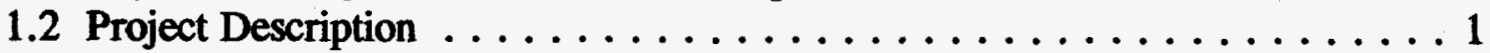

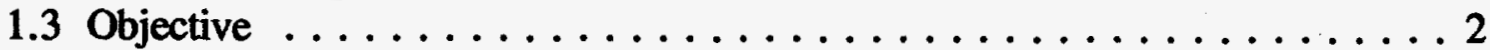

2.0 CONSTRUCTION RECOMMENDATIONS $\ldots \ldots \ldots \ldots \ldots \ldots \ldots \ldots$

3.0 SHORT-TERM STABILIZATION $\ldots \ldots \ldots \ldots \ldots \ldots \ldots \ldots \ldots$

3.1 Areas to be Stabilized $\ldots \ldots \ldots \ldots \ldots \ldots \ldots \ldots \ldots \ldots \ldots$

3.2 Product Selection . . . . . . . . . . . . . . . . . 4

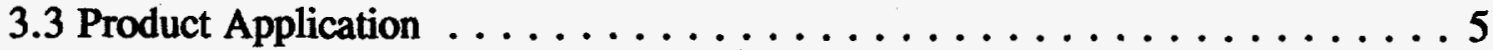

3.4 Monitoring the Effectiveness of Interim Soil Stabilization $\ldots \ldots \ldots \ldots \ldots 5$

4.0 LONG-TERM STABILIZATION: REVEGETATION $\ldots \ldots \ldots \ldots \ldots \ldots \ldots$

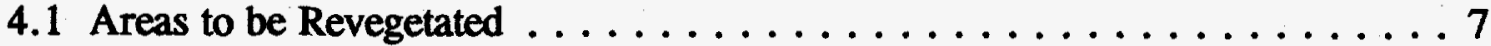

4.2 Soil Plant Growth Potential . . . . . . . . . . . . . . . . 7

4.3 Plant Species Selection . . . . . . . . . . . . . . . . 8

4.4 Site Access Requirements $\ldots \ldots \ldots \ldots \ldots \ldots \ldots \ldots \ldots$

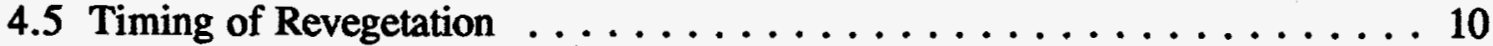

4.6 Site Preparation . . . . . . . . . . . . . . . . . . 10

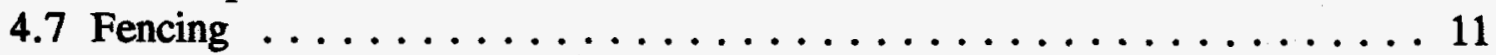

4.8 Reclamation Implementation $\ldots \ldots \ldots \ldots \ldots \ldots \ldots \ldots \ldots \ldots$

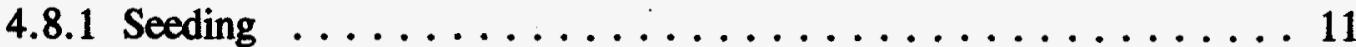

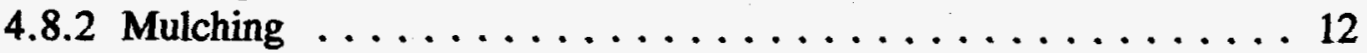

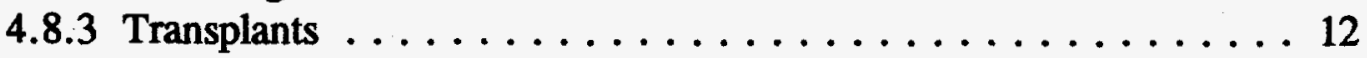

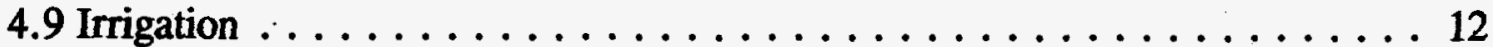

4.9.1 Irrigation Water Quality . . . . . . . . . . . . 13

4.9.2 Irrigation System Design and Implementation . . . . . . . . 14

4.9.3 Soil Moisture . . . . . . . . . . . . . . . . 15

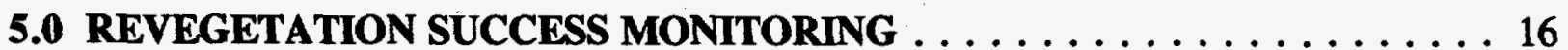

5.1 Reclamation Success Criteria . . . . . . . . . . . . . . 16

5.2 Reclamation Success: Vascular Plants . . . . . . . . . . . . 16

5.2 .1 Vascular Plant Density $\ldots \ldots \ldots \ldots \ldots \ldots \ldots \ldots \ldots \ldots$

5.2 .2 Vascular Plant Cover . . . . . . . . . . . . . . 17

5.3 Reclamation Success: Wildlife $\ldots \ldots \ldots \ldots \ldots \ldots \ldots \ldots \ldots \ldots$

5.4 Remediation Criteria $\ldots \ldots \ldots \ldots \ldots \ldots \ldots \ldots \ldots \ldots$

5.4 .1 Vascular Plant Density . . . . . . . . . . . . . 18

5.4 .2 Vascular Plant Cover . . . . . . . . . . . . . . 18

5.4 .3 Soil Properties $\ldots \ldots \ldots \ldots \ldots \ldots \ldots \ldots \ldots \ldots$ 
6.0 LITERATURE CITED $\ldots \ldots \ldots \ldots \ldots \ldots \ldots \ldots \ldots \ldots \ldots \ldots$

\section{LIST OF TABLES}

TABLE

PAGE

1. List of areas to be revegetated at Clean Slate 1 cleanup site $\ldots \ldots \ldots \ldots \ldots 7$

2. Perennial and annual species found in the reference area established at Clean Slate $3 \ldots \ldots \ldots \ldots \ldots \ldots \ldots \ldots \ldots$

3. Seed mix for revegetation of Clean Slate 1 cleanup site $\ldots \ldots \ldots \ldots \ldots$ 


\subsection{INTRODUCTION}

This document is a reclamation plan for short-term and long-term stabilization of land disturbed by activities associated with interim cleanup of radionuclide-contaminated surface soil at the Clean Slate 1 site. This document has been prepared to provide general reclamation practices and procedures that will be followed during restoration of the cleanup site. Reclamation demonstration plots were established near the Double Tracks cleanup site in the fall of 1994 to evaluate the performance of several native species and to evaluate different irrigation strategies. Results of that study, and the results from numerous studies conducted at other sites (Area 11 and Area 19 of the Nevada Test Site [NTS]), have been summarized and incorporated into this final reclamation plan for the cleanup of the Clean Slate 1 site. The plan also contains procedures for monitoring both short-term and long term reclamation.

\subsection{Physical Location and Setting of Cleanup Site}

The Clean Slate 1 cleanup site is located on the Tonopah Test Range (TTR). It is approximately $48 \mathrm{~km}$ (30 miles) from Tonopah, Nevada to the main gate. Typical access to the site is through the north entrance (main gate) to the TTR, south on Main Road for approximately 11 miles, east on Brownes Lake Road for approximately 4.5 miles, then south off of Brownes Lake Road for less than one mile.

Clean Slate 1 is located northeast of Antelope dry lake and elevations range from $1,637 \mathrm{~m}$ $(5,370 \mathrm{ft})$ to $1,640 \mathrm{~m}(5,380 \mathrm{ft})$. Common shrubs found inside the fenced area include budsage (Artemisia spinescens), winterfat (Ceratoides lanata), and shadscale (Atriplex confertifolia). Common grasses are galleta grass (Hilaria jamesii) and Indian ricegrass (Oryzopsis hymenoides). Soils are predominantly gravelly sandy loams (Leavitt, 1978). Average annual precipitation at Goldfield, located 30 miles to the west of the TTR, is $11.8 \mathrm{~cm}$ (5.22 in) (unpublished, Office of the Nevada State Climatologist).

\subsection{Project Description}

The Clean Slate 1 fenced area is approximately $160 \mathrm{~m}(525 \mathrm{ft})$ wide and $1,300 \mathrm{~m}(4,265 \mathrm{ft})$ long. The surface soils at Clean Slate 1 were contaminated as a result of the detonation of a device containing plutonium (Pu) and depleted uranium using chemical explosives (Church, 1969; Shreve, 1965). Cleanup of Clean Slate 1 will follow procedures similar to those used at the Double Tracks cleanup site. A maximum of approximately $15 \mathrm{~cm}(6$ in) of the surface soils will be excavated and removed from the site. Near ground zero, where contamination levels are highest, approximately $91 \mathrm{~cm}$ (36 in) of soil may be removed. The maximum area to be excavated is estimated to be 2.8 hectares ( 7 acres). In addition to the disturbance associated with soil excavation, an unknown number of hectares, but probably less than 2 hectares ( 5 acres), will be disturbed by the construction of staging areas and placement of support facilities. 


\subsection{Objective}

The primary objective of this document is to provide general procedures for short-term and long-term stabilization of soils that will be disturbed during the cleanup of contaminated soils at Clean Slate 1. Stabilization is critical to prevent any resuspension of residual $\mathrm{Pu}$ and to reestablish wildlife habitat. Short-term or interim stabilization consists of the application of a chemical soil stabilizer that is applied immediately following excavation of the contaminated soils to minimize Pu resuspension, thus reducing health hazards for workers and the public. Long-term stabilization, which is accomplished by the establishment of a permanent vegetative cover, will also reduce $\mathrm{Pu}$ resuspension, and is critical in returning the site to predisturbance conditions, thus providing habitat for local wildlife and complimenting the other actions being taken to release the site for future use.

A secondary objective is to give the procedures that will be used to ensure that both short-term and long-term stabilization are effective. The monitoring plan describes the procedures that will be used to evaluate the effectiveness of the chemical soil stabilizer in reducing resuspension of soil particles after excavation. The plan will also detail the procedures for collecting data from the areas that are revegetated and comparing those data with a standard for reclamation success. 


\subsection{CONSTRUCTION RECOMMENDATIONS}

Removal of topsoil during the excavation process leaves a soil low in organic matter and thus soil nutrients. In addition, the pool of seeds from native plants commonly found in the surface soils is lost. These two factors result in a sterile soil and difficult conditions for reestablishing a viable plant community. The following actions are recommended to ameliorate the effects of the loss of the topsoil during the cleanup process.

- Salvage the topsoil from the staging areas and the equipment loading/unloading zone, and any other major disturbances.

- Stockpile the salvaged topsoil on the up-slope side of the disturbed area.

- Topsoil stockpile should not exceed 2 meters (6 feet) in depth to maintain soil microbiological viability.

- During construction of new roads, any topsoil that is removed should be salvaged and stockpiled along side the road in berms not exceeding 2 meters (6 feet) in depth.

- During construction of topsoil stockpiles, traffic of earth moving equipment on top of the topsoil stockpile should be minimized.

- $\quad$ Topsoil stockpiles will be stabilized with a chemical stabilizer until soils are redistributed over disturbed areas.

- $\quad$ Reclamation scientist(s) should be on site during construction activities to assist in locating topsoil stockpiles and minimizing impacts to the environment.

- $\quad$ Construction equipment should travel on existing roads; no off-road travel should occur.

The reclamation scientist(s) will coordinate with the construction foreman to ensure that these recommendations are implemented. The areas where topsoil should be salvaged and the locations of the topsoil stockpiles will be included in the final reclamation plan. 


\subsection{SHORT-TERM STABILIZATION}

Short-term stabilization will be conducted after contaminated soils are excavated and verified to be within the established cleanup concentration levels of Pu. The duration of this phase will be as long as the excavation and verification processes may take. Short-term stabilization must remain effective until long-term stabilization occurs. To maintain effectiveness, reapplication of the soil stabilizer may continue until revegetation of the site occurs. The window for longterm stabilization (revegetation) is between October 1 and November 30. If excavation is completed outside this window, then short-term stabilization must continue until the site is revegetated.

\subsection{Areas to be Stabilized}

The highest priority for short-term soil stabilization will be the excavation area. The excavation area includes the area around ground zero and the area contaminated from the plume of the detonation. Additional areas impacted by the excavation process include access roads, usually on the perimeter of the excavation area, and stockpiles of excavated soils. Stockpiles will be stabilized when completed.

Short-term stabilization may also occur on miscellaneous disturbances during the excavation process, at the bagging operation, and after demobilization. Miscellaneous disturbances will include those areas disturbed prior to or during cleanup support activities. Some of the miscellaneous disturbances may become stabilized by natural soil crusting. These types of disturbance generally would not receive short-term soil stabilization unless it is deemed necessary to reduce fugitive dust and minimize the health risk to workers. Construction of the staging areas, inside and outside the fenced area, and the equipment loading/unloading area constitute the majority of the miscellaneous disturbances. A detailed figure showing all shortterm stabilization areas and areas to be revegetated will be included in the final reclamation plan.

After demobilization of excavation and bagging equipment, the soil surfaces in the staging areas inside and outside the fence will be ripped to alleviate the compaction of the soil (Section 4.6, Site Preparation) and disked to break up larger soil clods. Following ripping and disking, the soils may be stabilized again using Agri-Lock. Interim stabilization is necessary at this point because final stabilization will not occur until October or November and demobilization is tentatively scheduled for the end of May or early June.

\subsection{Product Selection}

Agri-Lock, a synthetic chemical soil stabilizer, was selected to be used for interim reclamation. Over the past couple years, numerous organic mulches, inorganic mulches, chemical stabilizers, soil surface manipulation treatments and windbreaks were evaluated. Each product or treatment was evaluated for its ability to 1) control wind erosion, 2) remain effective for at least five months, 3) be compatible with eventual revegetation of the site, 4) not introduce hazardous materials to the environment, 5) not pose a risk to workers, 6) show 
resistance to traffic, 7) not impede the verification process, 8) be compatible with the excavation process, 9) show compatibility with different soil types, and finally 10) be cost effective. Of the numerous products available in each of the aforementioned groups, eight representative products were field tested for erosion control capabilities, longevity of effectiveness, and effect on the emergence of seedlings. Based on the results of the original screening and the field trials, Agri-Lock was selected to be used for short-term stabilization. A full description of the selection process is described in a technical report that will be prepared for the U.S. Department of Energy in FY97.

Interim stabilization does not include active roads. Agri-Lock may not be the appropriate product for stabilization of disturbances that receive vehicular traffic. Examples of traffic resistant products include: petroleum byproducts, wood byproducts, and salts. These products should be applied to a compacted soil surface. Most require a pre-wetting treatment, although some products must be incorporated into the soil. This would reduce costs associated with hauling water for dust suppression. These products require much less water than a water-only soil-stabilization treatment and have an effective longevity of one to several months.

\subsection{Product Application}

Agri-Lock will be applied with a hydromulcher at a minimum rate of approximately 55 gallons/acre. The product will be diluted at a ratio of from 1:10 to 1:20 parts product to water. Application of Agri-Lock, like most chemical stabilizers, requires a pre-wetting of the soil. If soils exposed after excavation are not adequately wet, they may have to be wetted prior to application of Agri-Lock. If a dilution of 1:20 is used, a prewetting is less critical. Agri-Lock requires a curing time of one to three hours, depending on the wetness of the soil, air temperature and wind. After curing, the soil surface should be resistant to some light traffic. Repeated vehicular traffic may require reapplication. A wood fiber treated with a chemical dye may be used to act as a tracer or indicator of areas treated. The wood fiber should be applied at a rate of approximately $50 \mathrm{lbs} / 1,000$ gallons of water:product mixture.

\subsection{Monitoring the Effectiveness of Interim Soil Stabilization}

The effectiveness of interim soil stabilization will be monitored monthly. A staff scientist will conduct a meandering survey of the excavation area every four weeks following the initial application of Agri-Lock. The excavation area will be surveyed for signs of soil erosion, the occurrence of loose soil particles on the soil surface, major soil cracking thus exposing subsurface soil layers, and active rodent burrows, which usually result in subsurface soils being moved to the surface. The scientist will determine whether reapplication of Agri-Lock is necessary for the entire site, or for specific areas, such as recent rodent activity. Agri-Lock will be reapplied within two days of the survey. The same methods of application will be used. The rate of application may or may not be altered depending on the recommendation of the scientist conducting the survey.

A second evaluation of the effectiveness of interim soil stabilization may be made by the Desert Research Institute (DRI). The resuspension of soil particles will be measured using a wind tunnel. Measurements will be taken prior to interim soil stabilization, the day after 
interim stabilization, ten days after interim stabilization, and $\mathbf{3 0}$ days after interim stabilization. Results from the wind tunnel will be summarized. DRI scientists will evaluate the results of the wind tunnel. If resuspension of soil particles reaches a level considered to be excessive by DRI scientists, then reapplication or some other form of corrective action may occur. 


\subsection{LONG-TERM STABILIZATION: REVEGETATION}

The primary objective of long-term stabilization is to establish a stable plant cover that will reduce wind and water erosion, and reestablish wildlife habitat. Long-term stabilization is critical for minimizing fugitive dust and $\mathrm{Pu}$ resuspension, restoring the site to predisturbance conditions, and reestablishing habitat for wildlife. The potential for successful reclamation is enhanced by identifying soil plant growth potential, selecting appropriate plant species, using appropriate site preparation techniques, amending the soil, if needed, and implementing a tested arid-land revegetation strategy. The following sections outline the areas to be revegetated and the procedures to be used for revegetation at the Clean Slate 1 cleanup site.

\subsection{Areas to be Revegetated}

The following areas are to be revegetated during the fall of 1997 . The area to be revegetated is an estimate at this time. Exact acreages will be developed and included in the final reclamation plan.

Table 1. List of areas to be revegetated at the Clean Slate 1 cleanup site.

\begin{tabular}{|c|c|c|}
\hline Description & $\begin{array}{c}\text { Approximate } \\
\text { Size in meters (feet) }\end{array}$ & $\begin{array}{c}\text { Number of } \\
\text { Hectares (Acres) }\end{array}$ \\
\hline Ground Zero & $\begin{array}{l}\text { Exact dimensions to be } \\
\text { determined at later date }\end{array}$ & $\begin{array}{c}\text { Estimate of } 1.5 \text { ha } \\
\text { (3.7 a) }\end{array}$ \\
\hline Plume Area & $\begin{array}{l}\text { Exact dimensions to be } \\
\text { determined at later date }\end{array}$ & $\begin{array}{c}\text { Estimate of } 1.3 \mathrm{ha} \\
(3.3 \mathrm{a}) \\
\end{array}$ \\
\hline Staging Area: Inside Fence & $\begin{array}{c}\text { Based on size at Double } \\
\text { Tracks }\end{array}$ & 1 ha $(2.5$ a) \\
\hline Staging Area: Outside Fence & $\begin{array}{c}\text { Based on size at Double } \\
\text { Tracks }\end{array}$ & 0.4 ha $(1.0 \mathrm{a})$ \\
\hline Equipment Loading/Unloading & $\begin{array}{c}\text { Based on size at Double } \\
\text { Tracks } \\
\end{array}$ & $0.6 \mathrm{ha}(1.4 \mathrm{a})$ \\
\hline TOTAL ACREAGE TO BE REVEGETATED & & $\begin{array}{c}\text { Estimate } 4.8 \mathrm{ha} \\
\quad(11.9 \mathrm{a})\end{array}$ \\
\hline
\end{tabular}

Some roads may also be revegetated, as determined by the project manager, or they may be revegetated at a future date when monitoring activities are completed.

\subsection{Soil Plant Growth Potential}

The layer of exposed soil on the excavated areas at Clean Slate 1 has physical and chemical characteristics that will support plant growth. The uppermost layer $(30 \mathrm{~cm}[12 \mathrm{in}])$ of soil after excavation will have parameters consistent with those in the good suitability class 
(USDA, Forest Service, 1979; USDA, Soil Conservation Service, 1978). The results of soil analyses conducted by EG\&G in 1995 and Leavitt in 1978 on soils at Double Tracks were used to assess soil suitability. Overall the soils are slightly alkaline and organic matter is low. However, the plants in the area have adapted to such conditions and soil amendments to ameliorate the high $\mathrm{pH}$ and alkalinity would change conditions such that native species may not reestablish.

Soils in the Mojave and Great Basin deserts are generally low in organic matter. Since the top portion of the soil at Clean Slate 1 will be removed, most or all of the organic matter will be removed. Soils collected near the Clean Slate 1 cleanup site contain about $0.12 \%$ organic matter, substantially below the desired level of 0.5 to $1.5 \%$. The low percentage of organic matter results in a reduction in nutrients available to plants and the soil water holding capacity is lowered. To improve these soil conditions several actions will be taken. First, after the compacted soils have been ripped, a polyacrylamide gel will be applied to the site at a rate of $24 \mathrm{~kg} / \mathrm{ha}(20 \mathrm{lbs} / \mathrm{ac})$ using a drill seeder. Polyacrylamide gel crystals can improve the water holding capacity in the upper layer of the soil. Polyacrylamide gels (cross-linked polymer gels) can absorb 40 to 500 times their weight in water. At the NTS, polyacrylamide applications have been successful in increasing the numbers of germinating perennial species over areas not receiving the polyacrylamide application (EG\&G/EM 1994; EG\&G/EM 1995). After the gel has been applied, the plant material that was removed and salvaged from the excavation area will be returned to the site. The two materials will then be lightly (3-4 in) disked into the soil. A straw mulch will also be used following seeding (Section 4.8.1), which will also improve the percentage of organic matter in the soil.

\subsection{Plant Species Selection}

Vascular plant species native to the Clean Slate 1 area will be used to revegetate the cleanup area. To determine naturally occurring plants at the Clean Slate 1 site, vascular plant density and cover data were collected in July 1995 from 15 permanent, 50-m (164 ft) transects located in the southern-most corner of Clean Slate 3. The vegetation at Clean Slate 1 is similar to that found at Clean Slate 3. Vegetation data collected at Clean Slate 3 will serve as a reference for both Clean Slate 3 and Clean Slate 1. Density (absolute) was determined by averaging the number of plants occurring in five random $2 \times 2$-m quadrats on each of the 15 transects (Table 2). Relative percent density was calculated for each species by dividing the absolute percent density for a particular species by the total absolute percent density for all species combined. Relative density can be used to identify the proportion of an individual species' density in the total plant density of a site.

Plant cover was determined at the Clean Slate 1 site using a point-intercept method. Cover (absolute), defined as the percentage of ground surface area covered by the canopy of a particular species, was recorded for each perennial species along the transects (Table 2). Relative percent cover was calculated for each species by dividing the absolute percent cover for a particular species by the total absolute percent cover for all species (Table 2). 
Density and cover data were used in determining the species and proportion of each species to be included in the seed mix, and/or transplants used in revegetation of the Clean Slate 1 site. Annual plant species are not included because they do not provide constant vegetative cover. Other criteria used to select species for revegetation include: 1) previous success in establishing the species either by seeding or transplanting, 2) the ability to collect seed from native species in environments similar to the Clean Slate 1 site, and 3) the commercial availability of seed from species adapted to the Double Track environs.

Table 2. List of perennial plants found in the reference area established in the southeast corner of the Clean Slate 3 fenced area on the TTR. Percent density and cover values are given for species encountered on fifteen transects established in the reference area.

\begin{tabular}{|c|c|c|c|c|c|c|c|}
\hline \multirow[b]{2}{*}{ Scientific Name } & \multirow[b]{2}{*}{ Common Name } & \multicolumn{2}{|c|}{ Density } & \multicolumn{2}{|c|}{ Cover (\%) } & \multirow{2}{*}{$\begin{array}{c}\text { Seed } \\
\text { Commercially } \\
\text { Available }\end{array}$} & \multirow{2}{*}{$\begin{array}{c}\text { Seed } \\
\text { Collection } \\
\text { Feasible }\end{array}$} \\
\hline & & $\begin{array}{c}\text { Absolute } \\
\text { (plants } / \mathrm{m}^{2} \text { ) }\end{array}$ & $\begin{array}{c}\text { Relative } \\
(\%)\end{array}$ & Absolute & Relative & & \\
\hline \multicolumn{8}{|l|}{ Perennial species } \\
\hline Artemisia spinescens & Budsage & 0.7 & 9.0 & 2.1 & 13.8 & no & yes \\
\hline Atriplex confertifolia & Shadscale & 0.4 & 5.6 & 2.5 & 16.5 & yes & yes \\
\hline Ceratoides lanata & Winterfat & 1.0 & 13.2 & 5.1 & 34.4 & yes & yes \\
\hline Opuntia pulchella & Sand Cholla & $<0.1$ & $<0.1$ & 0.0 & 0.0 & no & no \\
\hline Aristida purpurea & Purple Threeawn & $<0.1$ & $<0.1$ & 0.0 & 0.0 & yes & yes \\
\hline Hilaria jamesii & Galleta Grass & 4.9 & 66.9 & 2.7 & 17.9 & yes & yes \\
\hline Oryzopsis hymenoides & Indian Ricegrass & 0.3 & 4.6 & 2.6 & 17.4 & yes & yes \\
\hline Sitanion hystrix & $\begin{array}{l}\text { Bottlebrush } \\
\text { Squirreltail }\end{array}$ & $<0.1$ & 0.6 & 0.0 & 0.0 & yes & yes \\
\hline & Totals & 73 & & 14.9 & & & \\
\hline
\end{tabular}

The seed mix for the Clean Slate 1 cleanup site contains three species of shrubs, four grasses and one forb (Table 3). The ratio of the different lifeforms in the seed mix is similar to that found on the reference sites, four shrubs and four grasses. No perennial forbs were encountered, but desert globe mallow (Spaeralcea ambigua) was added to the species mix because it is found frequently in the area.

Seed will be purchased from commercial sources, on a pure live seed (PLS) basis. Requests for seed purchased from commercial sources will carry the stipulation that seed origin be from Mojave and/or Great Basin desert environments.

\subsection{Site Access Requirements}

The Clean Slate 1 site should have an access with a width of at least $5 \mathrm{~m}(16 \mathrm{ft})$. Equipment that will be required at the site includes a tractor, road graders, disks, a harrow, flat bed truck, four wheel drive trucks, a seed drill, a hydromulcher, and a straw blower. 


\subsection{Timing of Reclamation}

Long-term stabilization will occur between October 1 and November 30. During this period, conditions are more favorable for meeting germination requirements of the seeded species. Seeding may occur later depending on climatic conditions, but seeding earlier is not recommended.

Table 3. Composition of seed mix to be used for revegetation of Clean Slate 1 cleanup site.

\begin{tabular}{|l|l|l|c|c|}
\hline Lifeform & Scientific Name & Common Name & of Seed Mix & $\begin{array}{l}\text { PLS kg/ha } \\
\text { (lbs/ac) }\end{array}$ \\
\hline Shrub & Artemisia spinescens & Budsage & 23.2 & $5.0(4.5)$ \\
\hline & Atriplex confertifolia & Shadscale & 1.0 & $0.2(0.2)$ \\
\hline & Ceratoides lanata & Winterfat & 51.5 & $11.2(10.0)$ \\
\hline Grasses & Aristida purpurea & Purple Threeawn & 1.5 & $0.3(0.3)$ \\
\hline & Hilaria jamesii & Galleta & 10.3 & $2.2(2.0)$ \\
\hline & Oryzopsis hymenoides & Indian Ricegrass & 10.3 & $2.2(2.0)$ \\
\hline \hline Forbs & Sitanion hystrix & Bottlebrush Squirreltail & 2.1 & $0.5(0.4)$ \\
\hline \hline Total PLS kg/ha (lbs/ac) & Desert Globe mallow & 0.9 & $0.2(0.2)$ \\
\hline
\end{tabular}

\subsection{Site preparation}

Site preparation will be completed prior to the October 1 to November 30, 1997 revegetation window. It is assumed that the soils will be compacted because water trucks will be used on the excavation site after excavation and prior to interim stabilization to control dust. The compaction will be alleviated by ripping to a depth commensurate with the degree of compaction, disking, and/or harrowing. These site preparation techniques increase water infiltration, and provide a firm seedbed for good soil-to-seed contact (Munshower, 1994). After ripping and disking, the staging areas, inside and outside of the fence, will be recontoured to approximately pre-disturbance conditions.

Any non-contaminated topsoils that were removed and stockpiled during cleanup activities will be used to return the site to predisturbance conditions. The topsoil will be evenly distributed over the site not to exceed 10-15 cm (4-6 in) deep. Disturbances will be recontoured to approximate pre-disturbance topographic conditions. 


\subsection{Fencing}

The fence currently surrounding the contaminated area at Clean Slate 1 should be left in place to reduce the effects of herbivores on plant establishment. This fence would primarily exclude horses and burros, but would not exclude rabbits and small rodents. The fence should remain in place for a minimum of five years, which should be sufficient time for plants to become established and able to withstand the effects of herbivory. Fencing may also be necessary around the staging area located outside the fenced area.

The effects of herbivores on new seedlings at the excavation area will be monitored during the growing season for the first two years. If herbivory is detected and is determined to be severe, i.e. may lead to the mortality of the majority of the plants, corrective action may be taken. If

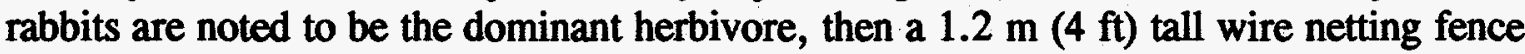
would be installed at the base of the existing fence.

\subsection{Reclamation Implementation}

The reclamation strategy that will be employed at the Clean Slate 1 site will include a combination of seeding and supplemental irrigation to increase the potential for the establishment of a native plant community during the first few years. The possibility of establishment occurring without seeding is remote because the native seed source in the native soils has been removed. Leaving the excavation area to reseed naturally would only promote an influx of annual species. The abundance of annual species often gives the appearance of restoration success, but their effectiveness in controlling erosion is short lived and undependable. Annual species are dependent on good growing conditions. During the past decade several years may pass in this region without good growing conditions and consequently the absence of annual plant species.

The overall objective of artificially seeding disturbed sites is to accelerate the natural restoration process by establishing a viable, native, perennial plant community. The establishment of perennial species will provide a more permanent means of controlling wind and water erosion throughout the growing season. Wildlife should adapt to the newly revegetated area because only species native to the area will be used in revegetation efforts.

\subsubsection{Seeding}

The Clean Slate 1 site will be seeded during the reclamation window, which is generally between October 1 and November 30. The preferable month for seeding is November. Seeding at this time ensures that dormancy-breaking requirements for germination of most seeded species would be met. Additionally, seed would be in the ground prior to winter precipitation and freezing temperatures. 
The seed will be broadcast-seeded at a rate of approximately 24.1 pure live seed (PLS) $\mathrm{kg} / \mathrm{ha}$ $(21.5 \mathrm{lbs} / \mathrm{ac})$. The area will be seeded with a tractor-drawn seed drill having seedboxes that accommodate small, fluffy, and large seeds. The disk openers on the drill will be elevated off the ground to allow seeds to be broadcast over the soil surface. After the seed is broadcast, the site will be harrowed with a tractor-drawn drag harrow to cover the seeds and improve soil-seed contact. Seeding and harrowing will be perpendicular to the slope of the site.

\subsubsection{Mulching}

Immediately after seeding, the site will be mulched with a grain (wheat or barley) straw at a rate of $4,500 \mathrm{~kg} / \mathrm{ha}(4,000 \mathrm{lbs} / \mathrm{ac})$. Mulching protects the soil surface from wind and water erosion, and also provides a more favorable micro-environment for seedling establishment. The mulch will be applied evenly to the soil surface with a truck-drawn straw blower. The mulch will then be secured to the soil surface via crimping.

A tractor drawn disk-crimper will be used to punch the straw into the soil. Crimping holds the straw in place, thus reducing erosion. Crimping incorporates a portion of the straw into the soil and over time can improve the amount of organic matter in the soil. The direction of crimping will be perpendicular to the slope of the site.

\subsubsection{Transplants}

Transplants are not planned to be used during initial revegetation in the fall of 1997. Transplanting may occur in subsequent years to increase species diversity on the site, if certain dominant species such as budsage are not reestablishing on the site. The number of transplants per hectare for budsage and other species that may be identified, would be determined from: 1) relative cover and density (Table 1) of the species in the native plant community, 2) desired percentage of a species density as transplants, 3) past success in establishment of the species from seeding or transplanting, and 4) the availability of transplants from either commercial nurseries or contract growers. Budsage is not available from plant nurseries, and it is unlikely that any of the other species are available either. If transplants are to be used it would be necessary to collect local seed and contract with a nursery to grow the desired number of plants. The decision to use transplants will be made the third or fifth growing season following initial revegetation.

\subsection{Irrigation}

One of the most limiting factors for successful seed germination and plant establishment is the availability of water. Precipitation amounts fluctuate from year to year at the Clean Slate 1 site, and extended periods of drought conditions could result in the complete failure of longterm soil stabilization attempts. Preliminary results from reclamation field study plots 
established at Double Tracks and at other sites on NTS suggest that irrigation improves seedling densities, which eventually results in the establishment of a stable perennial plant community. Results from these studies also suggest that irrigation during the late spring and early summer months improves survival of seeded species over the summer months (a report of the results of the studies will be prepared in FY97). Approximately $98 \%$ of the seedlings on study plots that were irrigated with $25 \mathrm{~mm}$ (1 inch) of water seven different times at intervals of 2-3 weeks during the late spring and early summer, survived the hot, dry summer months of 1995 . About $95 \%$ of the seedlings on plots irrigated with $50 \mathrm{~mm}(2 \mathrm{in})$, instead of $25 \mathrm{~mm}$ (1 inch) of water, survived, indicating that $25 \mathrm{~mm}$ ( 1 inch) is just as effective as 50 $\mathrm{mm}$ (2 in). Seedling survival on the two irrigated treatments was higher than on the plots that were not irrigated - $84 \%$ survival on non-irrigated plots as opposed to $95 \%$ on irrigated plots. Although the non-irrigated plots did not receive any supplemental irrigation, natural precipitation during the late spring and early summer was $83.6 \mathrm{~mm}(3.3 \mathrm{in})$, which created optimal growing conditions. In addition, temperatures during the summer of 1995 were moderate, and high temperatures did not occur until late in the summer. Under below-normal precipitation and poor growing conditions, irrigation would have had a more dramatic effect on seedling survival over the dry summer months.

Another study was conducted during the fall of 1995 and spring of 1996 to evaluate different irrigation strategies. One strategy tested was to irrigate in the fall to recharge the soil water levels, thus providing an environment more conducive to seed germination requirements. Another strategy was to irrigate just prior to seed germination in the spring of the year to provide an immediate source of water to ensure seed germination. A third strategy was a combination of the two. Results of the study suggest that seedling emergence is enhanced by fall or spring irrigations, as well as the combination of the two. In fact, seedling densities on non-irrigated plots were near zero. It was not possible to determine if different levels or intensities of irrigation were better than others. The study does, however, suggest that during years of poor growing conditions, irrigation is essential for establishing native plant species on disturbed sites.

\subsubsection{Irrigation Water Quality}

The assumption is also made that the quality of the available water will be sufficient for use in irrigation. To ensure this, a sample of water from the water source will be tested to determine the quality of the water. If the water quality is poor, actions must be taken to amend the water to improve the quality, or seek an alternative source. Ludwig et al. (1976) lists four basic criteria for evaluating water quality for irrigation purposes:

1) total soluble salt content (salinity hazard),

2) relative proportion of sodium cations to other cations (sodium hazard),

3) bicarbonate anion concentration as related to calcium plus magnesium cations, and

4) the concentration of elements that may be toxic. 
Total soluble salt is measured by electrical conductivity (EC). For irrigation water, the EC should not exceed $1.5 \mathrm{mmhos} / \mathrm{cm}$ (Ludwig et al., 1976). However, soil solutions should not have an EC greater than $4 \mathrm{mmhos} / \mathrm{cm}$ (Ries and Day, 1978).

The relative proportion of sodium cations is measured by the sodium adsorption ratio (SAR). Ludwig et al. (1976) recommend that the SAR for irrigation water not exceed 10. Water high in bicarbonate will tend to precipitate calcium carbonate and magnesium carbonate when the soil solution concentrates through evapotranspiration. This increases the SAR, which in turn, will increase the sodium hazard of the water to a level greater than that indicated by the SAR value. No upper limits were found for bicarbonates.

Devitt (1989) lists boron as one micronutrient that is essential for plant growth, but it becomes toxic to plant growth at levels exceeding $1 \mathrm{ppm}$. Fluoride is another element that limits plant growth when levels exceed 1 ppm (U.S. Environmental Protection Agency. 1983).

\subsubsection{Irrigation System Design and Implementation}

It is assumed that water will be available at the Clean Slate 1 site to irrigate the revegetated areas. The irrigation system used at the Clean Slate 1 site will be a solid-set sprinkler-type system designed to produce an even distribution of water across the entire reclaimed area. Sprinkler heads will be selected so as to apply water at the optimal rate and spray pattern. The sprinkler heads chosen will have a droplet size that maximizes distribution of water to the soil, minimizes runoff, and reduces wind drift.

Application of irrigation will include three implementation periods: pre-germination irrigation, germination irrigation, and establishment irrigation.

Pre-germination irrigation is the application of water to recharge the soil profile prior to germination of the seeded species. This recharge will encourage deep rooting and establishment of the seeded plants. Pre-germination irrigation will be implemented during late fall or winter after seeding, and will consist of the addition of approximately $80 \mathrm{~mm}(3.15 \mathrm{in}$.) of water to the soil over a 2 to 3-week period. Amount and frequency of application may vary based on climate conditions at the time of implementation.

Germination irrigation is defined as supplemental irrigation applied to initiate germination and seedling emergence. Germination irrigation can be adjusted by changing the amount applied during an irrigation event, the frequency of the events, and the duration of an irrigation event. Soil moisture cells will be placed in the upper $5 \mathrm{~cm}(2$ in) of soil to determine optimal application levels. Germination irrigation would begin in March and continue through May. Approximately $40 \mathrm{~mm}(1.6 \mathrm{in})$ of water would be applied over a 4 day period each of the three months. 
Establishment irrigation is the application of supplemental water following germination and seedling emergence. Establishment irrigation is used to supplement pre-germination irrigation by recharging the soil profile to encourage deep-rooting and survival of seedlings. As with germination irrigation, optimal application levels for establishment irrigation are dependent upon soil and climatic parameters. Typically, establishment irrigation would be initiated soon after seedling emergence and consist of the application of approximately $25 \mathrm{~mm}(1 \mathrm{in})$ of water every two weeks until July.

Irrigation is not scheduled to continue past the first growing season. The objective of irrigation is to create optimum conditions for the establishment of perennial shrub and grass species during the first growing season. After the first growing season perennial plants should be well enough established to withstand the growing conditions that may follow.

\subsubsection{Soil Moisture}

Soil moisture data is needed to determine amounts and frequency of germination and establishment irrigation, and to determine possible causes of reclamation failure. Soil moisture, in the top $5 \mathrm{~cm} \mathrm{(2} \mathrm{in)} \mathrm{of} \mathrm{soil,} \mathrm{will} \mathrm{be} \mathrm{monitored} \mathrm{with} \mathrm{soil} \mathrm{moisture} \mathrm{cells} \mathrm{(resistance}$ blocks) connected to a datalogger. 


\subsection{REVEGETATION SUCCESS MONITORING}

The objectives of revegetation success monitoring are to document and track the successful establishment of a stable vascular plant community on the disturbed site, and to document use of the site by wildlife. The success of reclamation will be determined by comparing plant and animal characteristics of the revegetated area to an adjacent reference or undisturbed area.

\subsection{Reclamation Success Criteria}

Revegetation success criteria or standards have been developed for the Clean Slate 1 cleanup site. These standards will also indirectly serve as standards for erosion control. Reclamation of the Clean Slate 1 site will be considered successful if, after ten years, plant density, cover, and the diversity of the reclaimed areas are $60 \%$ of that measured on the reference area during the same year. This percentage is based on the fact that complete restoration of the site would naturally take several decades (Angerer, et al. 1996) and that after one decade, if the site is within $60 \%$ of the native undisturbed reference area, it would appear to be on track for successful restoration.

To determine reclamation success, vascular plant cover and density will be measured on both the reclaimed area and the reference area over the next 10 years. Success for density will only consider those species that were seeded or native to the plant community surrounding the Clean Slate 1 site (Table 2).

\subsection{Reclamation Success: Vascular Plants}

After reclamation has occurred on the Clean Slate 1 site, 15 permanent, 50 -m transects, similar to those in the reference area (Section 4.3), will be randomly located within the revegetated excavation area. Vascular plant density, cover, and volumetric data on key perennial species will be measured along each of these transects and used for statistical comparisons with similar data collected from the reference area. These comparisons will be the basis for determining reclamation success.

The number of transects sampled will provide a level of precision that will allow the detection of a $10 \%$ change in the mean with $90 \%$ confidence. The formula is:

$$
N_{\min }=\left(\mathrm{t}_{.05}\right)^{2} 2\left(\mathrm{~S}^{2}\right) \div[(10 \%)(\bar{x})]^{2} \text {. }
$$

where $t=$ the two-tailed $t$ value at .10 significance with infinite degrees of freedom; $S^{2}=$ the variance; and $\bar{x}=$ the mean. Density estimates will be used to determine the minimum number of transects to sample. The total number of transects sampled will not exceed 15. If 15 are sampled, the confidence intervals will be determined and reported. 


\subsubsection{Vascular Plant Density}

Plant density will be measured to determine numbers of established plants, seedling emergence and plant survival. Density will be determined by recording the number of individual plants of each species occurring within each of five 4- $\mathrm{m}^{2}\left(43.1 \mathrm{ft}^{2}\right)$ quadrats randomly located along each permanent transect. Plant density will be sampled after each growing season during the first, third, fifth, and tenth year following reclamation. Composition data will be derived from density and/or cover data. Composition will be calculated for the reference and reclaimed areas in the third, fifth, and tenth growing season after revegetation.

\subsubsection{Vascular Plant Cover}

Ground cover is determined from the proportion of the ground surface covered by each of three categories: 1) living, above ground vegetation, 2) dead vegetative material (litter), and 3) bare ground. Each of these cover parameters is expressed as a percentage of the total area of measurement (Chambers and Brown, 1983). Ground cover data will be collected during the third, fifth, and tenth growing seasons.

Cover is determined using a cover-point optical point projection device (COPPD) (Buchner, 1985). The COPPD is positioned approximately $1 \mathrm{~m}$ (3.3 feet) above the ground and the plant species, litter, or bare ground that is intercepted by the theoretical vertical line is recorded. Cover parameters will be determined from four line intercepts or points recorded at two meter intervals along each $50-\mathrm{m}(163 \mathrm{ft})$ transect, or 100 points along each transect (4 points at 25 locations).

\subsection{Reclamation Success: Wildlife}

One of the objectives of reclamation of the Clean Slate 1 site is to return the site to provide habitat for wildlife. To document that the site is being used by wildlife, the presence of wildlife and/or signs of wildlife will be recorded during vegetation sampling. Wildlife observed on site will be noted as will signs of the presence of wildlife, such as scat, burrows, and browsed vegetation. These passive animal indicators will serve as an means to monitor use of the revegetated site by wildlife.

\subsection{Remediation Criteria}

Remediation, which involves some site preparation, reseeding, and remulching, will only be considered if reclamation of the site is not on track to meet the success criteria. Both vascular plant cover and density will be considered in determining the need for remedial reclamation. 


\subsubsection{Vascular Plant Density}

Plant density for the area surrounding the Clean Slate 1 site is approximately 7.3 plants $/ \mathrm{m}^{2}$ $\left(0.69 \mathrm{plants} / \mathrm{ft}^{2}\right)$. There were approximately $2 \mathrm{shrubs} / \mathrm{m}^{2}\left(0.19 / \mathrm{ft}^{2}\right)$ and $5 \mathrm{grasses} / \mathrm{m}^{2}\left(0.46 / \mathrm{ft}^{2}\right)$. To attain this density by the fifth growing season, a density of at least $10 \mathrm{shrub}$ seedlings $/ \mathrm{m}^{2}$ $\left(0.93\right.$ seedlings $\left./ \mathrm{ft}^{2}\right)$ and approximately 20 grass seedlings $/ \mathrm{m}^{2}\left(1.86 / \mathrm{ft}^{2}\right)$ of seeded or native species is necessary after the first growing season. If seedling density is significantly less than this after the first growing season, or less than 7.3 plants $/ \mathrm{m}^{2}$ after the third or fifth growing season, some form of remediation may be implemented to ensure successful reclamation of the site.

\subsubsection{Vascular Plant Cover}

Vascular plant cover will be measured in the third, fifth, and tenth years after reclamation. Data collected in year five will be used to evaluate the need for remedial reclamation. If vascular plant cover is below approximately $50 \%$ of the amount of cover on the reference area, remedial action may be necessary to ensure that reclamation success criteria are met.

\subsubsection{Soil Properties}

Soil on the reclaimed area may change over time as plants become established, soil amendments are added, or as salts build up from irrigation waters and rainfall. Soils from the reclaimed area will be monitored for conditions that may cause poor vascular plant establishment and/or growth. If such conditions are observed, soil samples may be retrieved from the top $30 \mathrm{~cm}$ (12 in) of soil and analyzed for key physical and chemical properties. The soil analyses will be used to identify the cause of poor growing conditions and to assist in developing remedial action(s). 


\subsection{LITERATURE CITED}

Angerer, J.P., W.K. Ostler, W.D. Gabbert, and B.W. Schultz. 1996. Secondary Succession on Disturbed Sites at Yucca Mountain, Nevada. EG\&G/EM Topical Report, EGG-11265-1118, Las Vegas, Nevada.

Buchner, D.L. 1985. Point Intercept Sampling in Revegetation Studies: Maximizing Objectivity and Repeatability, in Proceedings of the American Society for Surface Mining and Reclamation Meeting, October 1985, pp. 110-113.

Chambers, J.C., and R.W. Brown. 1983. Methods for Vegetation Sampling and Analysis on Revegetated Mined Lands. USDA Forest Service Intermountain Forest and Range Experiment Station General Technical Report, INT-151, Ogden, Utah. 57 pp.

Church, H.W. 1969. Cloud Rise From High-Explosives Detonations. Sandia National Laboratories Report, SC-RR-68-903, Albuquerque, New Mexico.

Devitt, D.A. 1989. Supplemental Irrigation in the Reclamation of Soils, in Reclamation of Mining-Disturbed Lands in the Great Basin. Nevada Cooperative Extension Shortcourse, October 3-4, 1989, Reno, Nevada.

EG\&G/Energy Measurements. 1994. Yucca Mountain Biological Resources Monitoring Program, Progress Report Oct. 1992 - Dec. 1993. EG\&G/EM Las Vegas Area Operations Report, EGG-11265-1073, Las Vegas, Nevada. 69 pp.

EG\&G/Energy Measurements. 1995. Yucca Mountain Biological Resources Monitoring Program, Progress Report Jan. 1994 - Dec. 1994. EG\&G/EM Las Vegas Area Operations Report, EGG-11265-1136, Las Vegas, Nevada. 79 pp.

Leavitt, V.D. 1978. Soil Surveys and Profile Descriptions of Plutonium-Contaminated Areas on the Test Range Complex in Nevada, 1970-1977, in Selected Environmental Plutonium Research Reports of the NAEG, M.G. White and P.B. Dunaway, Eds. U.S. Department of Energy Nevada Operations Office Report, NVO-192, Las Vegas, Nevada.

Ludwig, A.E., G.W. Hergert, and W.T. Franklin. 1976. Irrigation Water Quality Criteria. Colorado State University Extension Service, Service in Action Sheet no. 506. 2 pp.

Munshower, F.F. 1994. Practical Handbook of Disturbed Land Revegetation. Lewis Publishers, Boca Raton, Florida. 265 pp. 
Ries, R.E. and A.D. Day. 1978. Use of Irrigation in Reclamation in Dry Regions, in Reclamation Of Drastically Disturbed Lands, F.W. Schaller and P. Sutton, Eds. American Society of Agronomy, Madison, Wisconsin.

Shreve, Jr., J.D. 1965. Operation Roller Coaster, Scientific Director's Summary Report. Sandia National Laboratories Report, DASA-1644, Albuquerque, New Mexico.

U.S. Department of Agriculture, Soil Conservation Service. 1978. National Soils Handbook, Notice 24.

U.S. Department of Agriculture, Forest Service. 1979. User Guide to Soils. USDA Forest Service Intermountain Forest and Range Experiment Station General Technical Report, INT-68, Ogden, Utah. 80 pp.

U.S. Environmental Protection Agency. 1983. Hazardous Waste Land Treatment. Office of Solid Waste and Emergency Response Report, SW-874, Washington, D.C. 


\section{Distribution List}

U.S. Department of Energy Nevada Operations Office
S. Afong
M/S 505
M. Sanchez
M/S 505
Technical Information Resource Center
Public Reading Room
M/S 505
M/S NLV040

U.S. Department of Energy

Office of Scientific and Technical Information

P.O. Box 62, Oak Ridge, Tennessee 37831

Bechtel Nevada
R. Dodge
J. Kannard
M. Shotton
Correspondence Control
Project Files, c/o D. Anderson

M/S NLV082

M/S NLV022

M/S NLV082

M/S NLV008

M/S NLV081

IT Corporation
R. McKinley
M/S 439 
U.S. Department of Energy

Office of Scientific and Technical Information

P.O. Box 62, Oak Ridge, Tennessee 37831 